\title{
$\beta$ class II tubulin predominates in normal and tumor breast
} tissues

\author{
James H Dozier ${ }^{1}$, Laree Hiser ${ }^{2}$, Jennifer A Davis ${ }^{1}$, Nancy Stubbs Thomas ${ }^{2}$, Michelle A Tucci ${ }^{1}$, \\ Hamed A Benghuzzi ${ }^{3}$, Anthony Frankfurter ${ }^{4}$, John J Correia ${ }^{1}$ and Sharon Lobert ${ }^{2}$
}

${ }^{1}$ School of Medicine, University of Mississippi Medical Center, Jackson, Mississippi, USA

${ }^{2}$ School of Nursing, University of Mississippi Medical Center, Jackson, Mississippi, USA

${ }^{3}$ School of Health Related Professions, University of Mississippi Medical Center, Jackson, Mississippi, USA

${ }^{4}$ Department of Biology, University of Virginia, Charlottesville, Virginia, USA

Corresponding author: Sharon Lobert (e-mail: slobert@son.umsmed.edu)

Received: 1 Jul 2002 Revisions requested: 30 Aug 2002 Revisions received: 27 Jun 2003 Accepted: 7 Jul 2003 Published: 28 Jul 2003

Breast Cancer Res 2003, 5:R157-R169 (DOI 10.1186/bcr631)

(C) 2003 Dozier et al., licensee BioMed Central Ltd (Print ISSN 1465-5411; Online ISSN 1465-542X). This is an Open Access article: verbatim copying and redistribution of this article are permitted in all media for any purpose, provided this notice is preserved along with the article's original URL.

\begin{abstract}
Background: Antimitotic chemotherapeutic agents target tubulin, the major protein in mitotic spindles. Tubulin isotype composition is thought to be both diagnostic of tumor progression and a determinant of the cellular response to chemotherapy. This implies that there is a difference in isotype composition between normal and tumor tissues.
\end{abstract}

Methods: To determine whether such a difference occurs in breast tissues, total tubulin was fractionated from lysates of paired normal and tumor breast tissues, and the amounts of $\beta$ tubulin classes I + IV, II, and III were measured by competitive enzyme-linked immunosorbent assay (ELISA). Only primary tumor tissues, before chemotherapy, were examined. Her2/neu protein amplification occurs in about $30 \%$ of breast tumors and is considered a marker for poor prognosis. To gain insight into whether tubulin isotype levels might be correlated with prognosis, ELISAs were used to quantify Her2/neu protein levels in these tissues.

Results: $\beta$-Tubulin isotype distributions in normal and tumor breast tissues were similar. The most abundant $\beta$-tubulin isotypes in these tissues were $\beta$-tubulin classes II and I + IV. Her2/neu levels in tumor tissues were 5-30-fold those in normal tissues, although there was no correlation between the Her2/neu biomarker and tubulin isotype levels.

Conclusion: These results suggest that tubulin isotype levels, alone or in combination with Her2/neu protein levels, might not be diagnostic of tumorigenesis in breast cancer. However, the presence of a broad distribution of these tubulin isotypes (for example, $40-75 \% \quad \beta$-tubulin class II) in breast tissue, in conjunction with other factors, might still be relevant to disease progression and cellular response to antimitotic drugs.

Keywords: antimitotic agents, breast cancer, microtubules, tubulin isotypes

\section{Introduction}

Common agents currently used in treating metastatic breast cancer are the antimitotics paclitaxel and docetaxel $[1,2]$. These drugs bind to $\beta$-tubulin, a major protein in mitotic spindles, and halt cell division at metaphase. Their effectiveness in cancer chemotherapy is thought to be due to their ability to reduce the dynamics of microtubules in mitotic spindles, thus preventing spindle assembly and interrupting the normal movement of sister chromatids toward the spindle poles [3-9]. Tubulin, a $100 \mathrm{kDa} \alpha \beta$ heterodimer, is structurally heterogeneous, with seven genes encoding $\alpha$-tubulin and $\beta$-tubulin isotypes. The major differences between isotype classes reside in the last 15-20 amino acids of the carboxy-termini [10,11],

$\mathrm{BCIP}=5$-bromo-4-chloroindol-3-yl phosphate; cDNA = complementary DNA; EGTA = (ethylene-bis[oxyethylenenitrilo])tetraacetic acid; CHTN = Cooperative Human Tissue Network; ELISA = enzyme-linked immunosorbent assay; MAP = microtubule associated protein; MES $=2$ - $(N$ morpholino)-ethane sulfonic acid; NBT = nitro blue tetrazolium; PBS = phosphate-buffered saline; PC-tubulin = MAP-free phosphocellulose-purified tubulin; PCR = polymerase chain reaction; PIPES = piperazine- $N, N^{\prime}$-bis(2-ethanesulfonic acid); PVDF = poly(vinylidene difluoride). 
and these differences have been exploited in the development of isotype-specific antibodies [12-14]. Mammalian microtubules are formed from a mixture of $\alpha$-tubulin and $\beta$-tubulin isotype classes $[11,15,16]$, and the antimitotics used in chemotherapy interact primarily with $\beta$-tubulin. In vertebrates the concentrations of the specific isotypes vary in different tissues [11,17], although the functional role for the variability in tubulin polypeptides is uncertain $[17,18]$.

The expression of genes encoding $\alpha$-tubulin and $\beta$-tubulin seems to be developmentally regulated [19]. For example, tubulin isotype expression patterns change during the development and maturation of neurons $[14,20]$. Studies with paclitaxel or other antimitotic agents, such as colchicine or estramustine, indicate that drug interactions with tubulin isotypes differ [21-25] and might contribute to cell resistance to antimitotics [26-31]. However, one group of antimitotic agents, the vinca alkaloids, was shown to bind with similar affinity to all tubulin isotypes [12], suggesting that alterations in drug binding affinity is unlikely to be the cause of drug resistance. Furthermore, whereas some of these data suggest a role for tubulin isotypes in drug resistance, cell growth, and differentiation, other work indicates that isotype-independent factors affecting microtubule polymer formation are more important than changes in isotype levels [32-35]. For example, a decrease in total polymer concentrations causes resistance to microtubulestabilizing agents such as paclitaxel [34,35].

The work presented here quantitatively compares the tubulin isotype levels in normal and tumor breast tissues. We developed an indirect, competitive enzyme-linked immunosorbent assay (ELISA) using antibodies specific for $\beta$-tubulin classes II, III and I + IV that is sensitive to $1 \mu \mathrm{g} / \mathrm{ml}$ tubulin. The results of the ELISA assay agree with quantitative Western blotting and indicate that $\beta$-tubulin class II predominates in both normal and tumor breast tissues. Isotype levels are similar in both tissues, but surprisingly they exhibit a broad fractional distribution. To explore this further we measured Her2/neu protein levels, which are known to be correlated with poor prognosis. We demonstrate that although Her2/neu levels in tumor tissues were 5-30-fold those in normal tissues, there was no correlation between the Her2/neu biomarker and tubulin isotype levels. Taken together, these data suggest that, unlike previous reports on small cell lung cancer [36], $\beta$-tubulin isotype levels are not diagnostic markers in breast cancer. These results challenge the hypothesis of a universal role for tubulin isotypes in tumor growth and the development of drug resistance. Nevertheless, we cannot exclude the possibility that changes in the distribution of tubulin isotypes in normal and tumor breast tissue, in conjunction with other molecular factors, might still be relevant to disease progression and cellular response to

\section{Materials and methods Reagents}

$\mathrm{MgSO}_{4}$, (ethylene-bis[oxyethylenenitrilo])tetraacetic acid (EGTA), GTP (type II-S), glycerol, 2-(N-morpholino)ethane sulfonic acid (MES), Nonidet P 40, piperazine$N, N^{\prime}$-bis(2-ethanesulfonic acid) (PIPES) and Triton X-100 were purchased from Sigma Chemical Company. Sephadex G-50 was from Pharmacia. Nitro blue tetrazolium (NBT), 5-bromo-4-chloroindol-3-yl phosphate (BCIP) and poly(vinylidene difluoride) (PVDF) were from Bio-Rad. Deionized (Nanopure) water was used in all experiments.

\section{Purification of tubulin from pig brain}

Phosphocellulose-purified tubulin (PC-tubulin) free of microtubule-associated proteins (MAPs) was obtained by warm/cold polymerization/depolymerization with the addition of a final phosphocellulose chromatography step to separate tubulin from MAPs [37,38]. Tubulin concentrations were determined spectrophotometrically, using $\varepsilon_{278}=1.2 \mathrm{~L} /(\mathrm{g} \mathrm{cm})$ [39].

\section{Cell culture and Her2/neu ELISAs}

The breast cancer cell lines MCF-7 and HCC1954 were obtained from American Type Culture Collection and grown under the recommended conditions. MCF-7 cells are known to have fewer than five copies of the Her2/neu gene, whereas HCC1954 cells overexpress the protein because of gene amplification $[40,41]$. Her2/neu protein levels were determined with a Her2/neu ELISA kit (Oncogene) in accordance with the manufacturer's instructions. This ELISA kit was also used to determine Her2/neu protein levels in tissue samples.

\section{Tissue preparation and tubulin fractionation}

Anonymous paired tumor $(n=20)$ and normal $(n=20)$ breast tissue samples $(0.25-1.0 \mathrm{~g})$, quick-frozen in liquid nitrogen within 1 hour of surgery, were provided by the Cooperative Human Tissue Network (CHTN, National Cancer Institute) (Table 1). Pathology reports were provided by CHTN for each tissue sample. Only primary tumor samples were examined. Normal tissue was taken from the same breast at a site distant from the tumor and evaluated for the presence of tumor cells. The patients in the study, ages ranging from 28 to 92 years, had not received prior radiation or chemotherapy. The diagnosis of each patient is shown in Table 1. Tissue samples were homogenized in a Dounce homogenizer on ice in $1 \mathrm{ml}$ of lysis buffer $\left(25 \mathrm{mM}\right.$ MES, $1 \mathrm{mM} \mathrm{MgSO}_{4}, 2 \mathrm{mM}$ EGTA, $0.1 \mathrm{mM}$ GTP, $0.1 \%$ Triton X-100 with a protease inhibitor cocktail [Complete Protease Inhibitor Tablets; Boehringer Mannheim]).

Membranes were removed by pelleting at $4^{\circ} \mathrm{C}$ in a microcentrifuge for $5 \mathrm{~min}$. Membrane lipids remained at the top of the sample and a tiny pellet was often also observed. 
Table 1

\begin{tabular}{ll}
\multicolumn{1}{l}{ Tumor and normal tissue samples } \\
\hline Sample & Patient diagnosis \\
\hline T1/N1 & Phyllodes tumor \\
T2/N2 & Infiltrating ductal carcinoma \\
T3/N3 & Invasive poorly differentiated carcinoma \\
T4/N4 & Infiltrating ductal carcinoma \\
T5/N5 & Invasive ductal carcinoma \\
T6/N6 & Intraductal and invasive ductal carcinoma \\
T7/N7 & Invasive ductal carcinoma \\
T8/N8 & Infiltrating adenocarcinoma \\
T9/N9 & Infiltrating ductal carcinoma \\
T10/N10 & Infiltrating ductal carcinoma \\
T11/N11 & Infiltrating ductal carcinoma \\
T12/N12 & Infiltrating lobular carcinoma \\
T13/N13 & Metastatic adenocarcinoma \\
T14/N14 & Infiltrating lobular carcinoma \\
T15/N15 & Invasive ductal carcinoma \\
T16/N16 & High-grade invasive carcinoma \\
T17/N17 & Infiltrating ductal carcinoma \\
T18/N18 & Infiltrating ductal carcinoma \\
T19/N19 & Adenocarcinoma \\
T20/N20 & \\
Tiltrating ductal carcinoma \\
\hline
\end{tabular}

Tissue samples: $\mathrm{T}$, tumor, $\mathrm{N}$, normal.

The pellet was not sufficiently large to allow the determination of protein levels with our assay. The total protein concentration in the supernatant (separated from the lipid fraction) was determined with the Advanced Protein Assay Reagent (Cytoskeleton Inc). The supernatant was then loaded on a $2 \mathrm{ml}$ arginine-Sepharose column equilibrated with the MES buffer above without Triton X-100. The procedure for arginine-Sepharose purification of tubulin was presented in detail by Lacey and Snowdon [42]. An enriched tubulin fraction was collected in high-salt MES buffer (2.5\% ammonium sulphate) and equilibrated in $10 \mathrm{mM}$ Pipes, pH6.9, $2 \mathrm{mM}$ EGTA, $1 \mathrm{mM} \mathrm{MgSO}_{4}$, $0.05 \mathrm{mM}$ GDP, $0.01 \%$ Triton $\mathrm{X}-100$, using a spun column. The tubulin fractions were used in the ELISA and/or Western blotting experiments. The same procedure was used to fractionate pig brain samples to quantify tubulin isotypes by Western blotting.

To ensure that arginine-Sepharose chromatography did not preferentially fractionate specific tubulin isotypes, microtubule protein fractions from an early stage in purification (tubulin plus MAPs) were examined by ELISAs and Western blotting. There were no differences before and
Table 2

\begin{tabular}{lccc}
\multicolumn{4}{l}{ Tubulin isotypes in pig brain } \\
\hline Location & $\beta$ I + IV (\%) & $\beta$ II (\%) & $\beta$ III (\%) \\
\hline Cerebellum & $17.7 \pm 4.1$ & $52.6 \pm 8.3$ & $28.5 \pm 5.2$ \\
Right cerebrum & $14.1 \pm 2.9$ & $53.5 \pm 5.4$ & $30.7 \pm 4.5$ \\
PC-tubulin & $18.1 \pm 9.1$ & $54.1 \pm 7.2$ & $27.8 \pm 4.3$ \\
\hline
\end{tabular}

after arginine-Sepharose fractionation in the percentages of any of the $\beta$-tubulin isotypes tested in this study (data not shown).

\section{Quantitative Western blotting}

The monoclonal antibodies used in the studies, TUJ1 (anti$\beta$-tubulin class III), 7H12 (anti- $\beta$-tubulin classes I + IV), and 7B9 (anti- $\beta$-tubulin class II), have been characterized previously $[13,14]$ and are highly specific for their epitopes. Sequential immunoaffinity columns were used to purify $\beta$-tubulin classes II and III with their associated $\alpha$-tubulins as described previously [12]. Known amounts of PC-tubulin, $\beta$-tubulin classes II and III, and pig brain samples $(n=12)$ from the cerebellum and right cerebrum were examined by SDS-polyacrylamide-gel electrophoresis and transferred to PVDF filters [43]. Alkaline phosphatase colorimetric reactions (NBT and BCIP) were used to identify tubulin isotypes. Triplicate blots for each sample were analyzed by densitometry (Molecular Dynamics with ImageQuant Software). The linearity of response was established by systematically varying the amounts of known tubulin loaded into wells and plotting these values against densitometry results by using Origin 5.0 (Microcal). These comparisons allowed us to calibrate the amounts of $\beta$-tubulin classes I + IV, II, and III in PC-tubulin and in pig brain samples (Table 2). The same procedures were used to quantify $\beta$-tubulin in five tumor and normal breast tissues for comparison with the ELISA results.

\section{Tubulin isotype ELISAs}

Indirect, competitive ELISAs were used to quantify the tubulin isotypes in tissue samples. The method is adapted from standard protocols for indirect ELISAs [44]. The indirect ELISA involves the titration of antibodies reacted with tubulin in solution. A known amount of tubulin is mixed with the unknown sample; the antibodies compete with a known amount of tubulin bound to the plate. A secondary antibody generates the signal used to quantify the unknown protein. The amount of known protein can be adjusted to optimize the sensitivity of the assay.

Optimal tubulin binding ( $75 \mu \mathrm{g} / \mathrm{ml}, 50 \mu \mathrm{l}$ per well) to polystyrene microtiter plates (96 wells; Nalge NUNC International) was performed overnight at $4^{\circ} \mathrm{C}$ in a humid environment. Plates were then washed three times with 
phosphate-buffered saline (PBS) and blotted dry. The average values in pig brain tissues for each isotype (53\% $\beta$ class II, $17 \% \beta$ classes I + IV, and 29\% $\beta$ class III; determined as described above; Table 2) were used to construct standard curves in the tubulin isotype ELISA assay. Duplicate standard curves for each antibody were made with PC-tubulin (final concentration $150 \mu \mathrm{g} / \mathrm{ml}, 3 \%$ nonfat dried milk in PBS). Duplicate unknown tissue samples were prepared by combining them with known levels of PC-tubulin (1:1), then mixing them 1:1 with antibody in $3 \%$ nonfat dried milk in PBS.

Antibodies (usually about $1 \mathrm{mg} / \mathrm{ml}$ ) against $\beta$-tubulin classes I + IV (7H12), II (7B9), and III (TUJ1) were used at optimal dilutions (ranging from $1: 500$ to $1: 10000$ ) determined empirically for each new stock of antibody. Serial dilutions $(50 \mu \mathrm{l}$ per well) were performed, varying only the protein concentration and keeping the antibody and nonfat dried milk concentrations constant. Plates were left at $22^{\circ} \mathrm{C}$ under mild humidity for 2 hours on a shaker and then washed four times with PBS and blotted dry before addition of the secondary horseradish peroxidase-conjugated antibody (Sigma) in 3\% nonfat dried milk in PBS. Secondary antibody concentrations were optimized for each new stock. After 2 hours at $22^{\circ} \mathrm{C}$ on a shaker, plates were washed four times with PBS, blotted dry and reacted with tetramethylbenzidine $(50 \mu \mathrm{l}$ per well). The reaction was stopped with $1 \mathrm{M}$ sulfuric acid, and plates were read at $450 \mathrm{~nm}$ in a 96-well plate reader (TECAN, Research Triangle Park, North Carolina).

Data were fitted by nonlinear least squares, using Fitall (MTR software, Toronto, Canada) modified with an exponential fitting function. This fitter globally fits the standard curve and the sample data to extract the amplitude, the exponential curvature, and the amount of tubulin isotype in the breast tissue sample. Typical ELISA data are shown in Fig. 1. In developing the quantitative tubulin ELISA, either microtubule protein from pig brain containing unknown amounts of tubulin or a known amount of PC-tubulin was used as the experimental sample. This permitted a determination of the accuracy of our quantification. The experiments with microtubule protein resulted in isotype percentages similar to those determined by quantitative Western blotting. Isotype determinations with the experimental samples made with known PC-tubulin were, within error, the same as the expected quantities (data not shown).

The reliability of the tubulin ELISA is indicated by comparison with quantitative Western blotting of breast tissue samples (Figs 2 and 3). Five paired anonymous normal and anonymous tumor samples were obtained in $1-2 \mathrm{~g}$ quantities sufficient for quantitative Western blotting (kindly provided by Dr Terry Hall, University of Mississippi Medical Center, Jackson, Mississippi). There is no signifi-
Figure 1

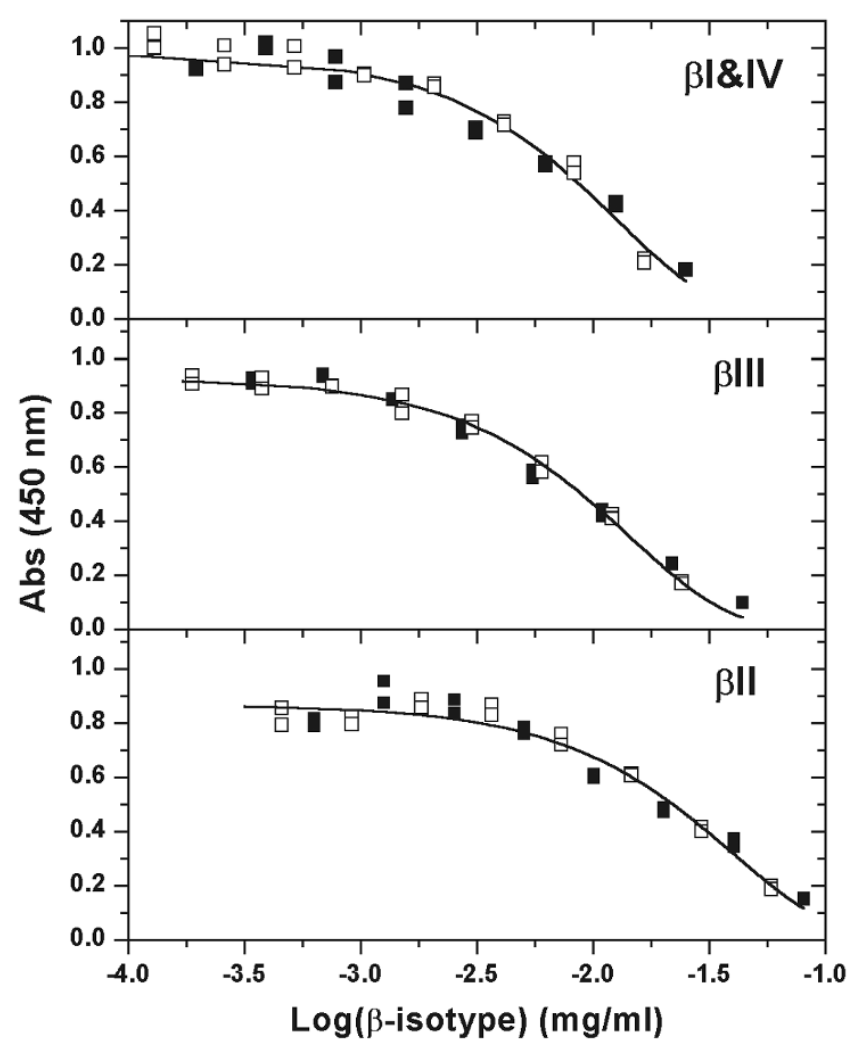

A typical set of ELISA data, standard curve (filled squares) and sample (open squares), are presented with the best fits of the data. The duplicate standards and sample data are globally fitted to an exponential function $A \exp \left(c_{i}+\beta_{i} / \tau\right)$, where $c_{i}$ is the concentration of (PC-tubulin-derived) $\beta$-tubulin isotype in each dilution and $\beta_{i}$ is the concentration of breast tissue $\beta$-tubulin isotype in each sample, corrected for dilution. The sample data are then corrected for this additional concentration of breast tissue isotype and plotted with the standard curve and the best fit to demonstrate the goodness of fit. Fits of these data resulted in the following concentrations for $\beta$-tubulin classes: I + IV, $4.09 \mu \mathrm{g} / \mathrm{ml}$; III, $2.27 \mu \mathrm{g} / \mathrm{ml}$; II, $18.34 \mu \mathrm{g} / \mathrm{ml}$. Triplicate ELISA data for each tissue sample were fitted separately and then averaged to give the final results and standard deviations (Fig. 5).

tions of tubulin isotypes. However, $\beta$-tubulin classes II and I + IV fractions vary widely: $0.23-0.54$ and $0.20-0.67$, respectively. $\beta$-Tubulin class III values are relatively constant, $0.20-0.27$ (with the exception of one pair, 0.09 and 0.11 for tumor [T4] and normal [N4]; Fig. 3). These wide distributions for $\beta$-tubulin classes II and I + IV agree with the ELISAs for the larger study of 40 additional samples from CHTN presented here $(0.41-0.76$ and $0.10-0.46$, respectively). Note also that, unlike for breast tissues, quantitative Western blot analyses of pig brain samples demonstrate relatively constant tubulin isotype fractions described above (Table 2). The values for each isotype in pig brain are in reasonable agreement with the values previously reported $(58 \%, 25 \%$, and $13 \%$ for $\beta$-tubulin classes II, III, and IV) [45], further establishing the validity 
Figure 2

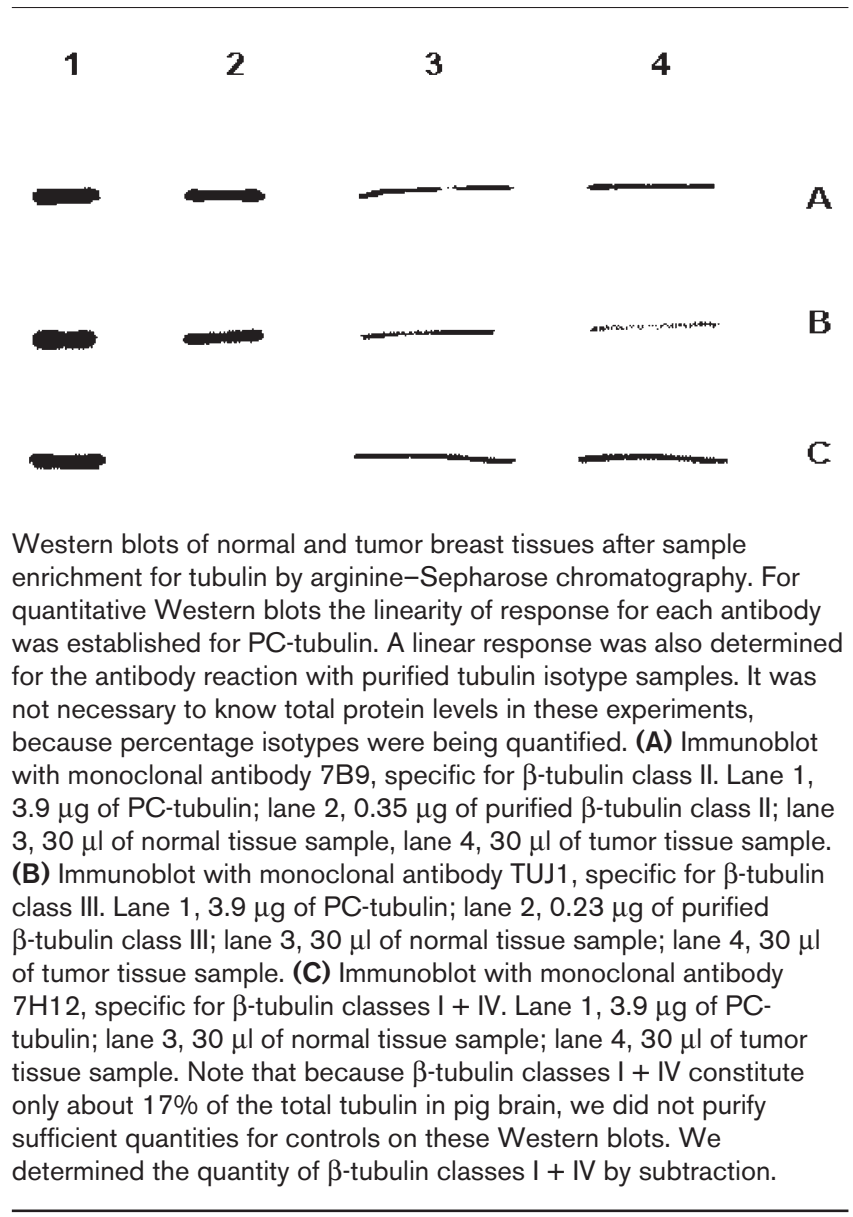

of this approach. This result supports the accuracy and the sensitivity of the quantitative Western blots and ELISAs and demonstrates that the wide distribution observed for $\beta$-tubulin classes II and I + IV in breast tissues is not due to error in measurement.

\section{Immunohistochemistry}

Tissues were fixed in $10 \%$ buffered formalin containing $2 \%$ zinc sulfate to preserve antigenic sites, then embedded in paraffin, and sectioned on a Zeiss rotary microtome. Trypsin digestion was performed at $22^{\circ} \mathrm{C}$ for $15 \mathrm{~min}$ and followed by a wash with soybean trypsin inhibitor. The slides were de-paraffinized with a total of three incubations in xylene, rehydrated through a graded alcohol series beginning with 100\%, 95\%, 70\%, and 50\% in PBS, and treated with $0.3 \%$ hydrogen peroxide in methanol to quench the endogenous peroxidase activity. The sections were blocked in 5\% powdered skimmed milk in PBS ( $\mathrm{pH}$ 7.4) and incubated overnight in a humid chamber at $4^{\circ} \mathrm{C}$ with primary monoclonal antibodies. The slides were washed with four changes of PBS, and incubated with a working dilution of biotin-labeled anti-mouse secondary antibody and avidin-biotin-peroxidase complex (ABC).

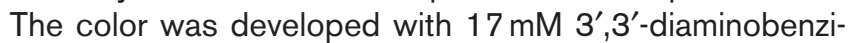

Figure 3

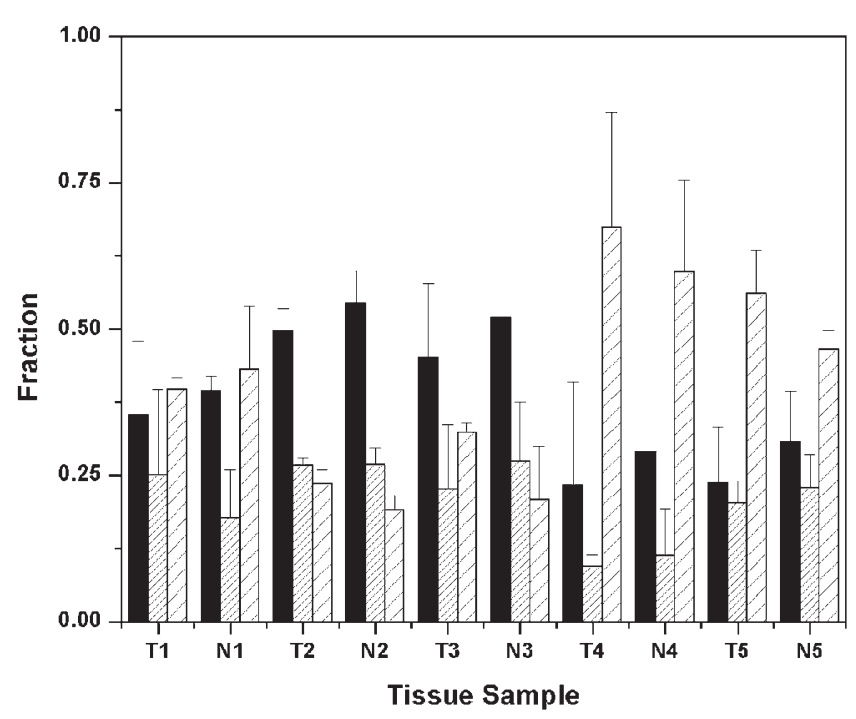

Bar graph showing the tubulin isotype distribution determined by quantitative Western blotting in five paired normal and tumor breast tissue samples. Bars: black, $\beta$-tubulin class II; dense hatch, $\beta$-tubulin class III; sparse hatch, $\beta$-tubulin classes I + IV. Results are means and SDs for duplicate blots.

dine, $40 \mathrm{mM}$ hydrogen peroxide in $0.5 \mathrm{mM}$ Tris- $\mathrm{HCl}$ buffer (pH 5.0). The sections were counterstained with Gill's hematoxylin, dehydrated, and mounted. Negative controls were performed by omission of the primary antibody, and positive controls for tubulin isotypes were performed with pig brain tissues.

\section{Real-time polymerase chain reaction (PCR)}

Real-time PCR was used to determine tubulin isotype mRNA levels in selected breast tissues (Table 1: T1, N1, T4, N4, T12, N12, T13, N13, T15, N15, T18, N18, N6, and T14). All the other breast tissue samples were required in their entirety for the ELISA and immunohistochemistry experiments. The purpose of these real-time PCR experiments was to establish whether tubulin protein levels were correlated with mRNA levels. We developed protocols for quantitative two-step reverse transcriptase PCR to establish the relative amounts of mRNA transcripts encoding each of the $\beta$-tubulin isotypes (classes I, II, III, IVa, IVb, V, and VI). Total RNA was extracted from $5 \times 10^{6}$ cells with the Micro-to-Midi' ${ }^{\text {TM }}$ Total RNA Purification System (Invitrogen). The purity of the RNA was assessed by $A_{260}: A_{280}$ ratios. Electrophoresis with RNA 6000 LabChips $^{\mathrm{TM}}$ and an Agilent 2100 Bioanalyzer was used to determine the integrity of ribosomal RNA. The RNA concentration was calculated from $A_{260}$ ( 1 absorbance unit $=40 \mu \mathrm{g} / \mathrm{ml}$ ) or obtained directly from the bioanalyzer. Before the reverse transcription reaction, genomic DNA contamination was eliminated by digestion with deoxyribonuclease I (amplification grade; Sigma). 
Table 3

\begin{tabular}{|c|c|c|c|c|}
\hline$\beta$-Tubulin gene & Description & Sequence $\left(5^{\prime} \rightarrow 3^{\prime}\right)$ & $T_{\mathrm{m}}\left({ }^{\circ} \mathrm{C}\right)$ & $\begin{array}{c}\text { Amplicon length } \\
\text { (base pairs) }\end{array}$ \\
\hline Class I & $\begin{array}{l}\text { Forward } \\
\text { Reverse }\end{array}$ & $\begin{array}{l}\text { CCCCATACATACCTTGAGGCGA } \\
\text { GCCAAAAGGACCTGAGCGAA }\end{array}$ & $\begin{array}{l}59.8 \\
59.1\end{array}$ & 289 \\
\hline Class II & $\begin{array}{l}\text { Forward } \\
\text { Reverse }\end{array}$ & $\begin{array}{l}\text { ACGGGTTAGGGAAAGCGGA } \\
\text { TTCCGACACAAACGTTTATGTGA }\end{array}$ & $\begin{array}{l}59.6 \\
56.7\end{array}$ & 241 \\
\hline Class III & $\begin{array}{l}\text { Forward } \\
\text { Reverse }\end{array}$ & $\begin{array}{l}\text { ATGCGGGAGATCGTGCACAT } \\
\text { CCCCTGAGCGGACACTGT }\end{array}$ & $\begin{array}{l}60.6 \\
60.0\end{array}$ & 238 \\
\hline Class IVa & $\begin{array}{l}\text { Forward } \\
\text { Reverse }\end{array}$ & $\begin{array}{l}\text { TCTCCGCCGCATCTTCCA } \\
\text { GCTCTGGGGACATAATTTCCTCCT }\end{array}$ & $\begin{array}{l}59.8 \\
60.0\end{array}$ & 272 \\
\hline Class IVb & $\begin{array}{l}\text { Forward } \\
\text { Reverse }\end{array}$ & $\begin{array}{l}\text { GCTGTTTGTCTACTTCCTCCTGCT } \\
\text { CAGTTGTTCCCAGCACСАCTCT }\end{array}$ & $\begin{array}{l}60.4 \\
60.8\end{array}$ & 344 \\
\hline Class V & $\begin{array}{l}\text { Forward } \\
\text { Reverse }\end{array}$ & $\begin{array}{l}\text { CGGGGAGGAAGCTTTTGAGGAT } \\
\text { CTGGGTAGAACCCGCAATTCTCT }\end{array}$ & $\begin{array}{l}60.5 \\
60.2\end{array}$ & 244 \\
\hline Class VI & $\begin{array}{l}\text { Forward } \\
\text { Reverse }\end{array}$ & $\begin{array}{l}\text { AGTTGTGTTGGGCTCACACCA } \\
\text { TTGCCACACTGGCCAATCTGA }\end{array}$ & $\begin{array}{l}60.8 \\
60.9\end{array}$ & 133 \\
\hline
\end{tabular}

$T_{\mathrm{m}}$ values were calculated for reaction conditions containing $50 \mathrm{mM} \mathrm{NaCl}$.

To minimize differences in efficiency of the reverse transcription reaction, the various isotype complementary DNAs (cDNAs) were produced in a single tube. Aliquots were then used in quantitative PCR to determine the relative amount of each isotype cDNA independently. PCR reactions were performed with isotype-specific primer pairs for $\beta$-tubulin isotype classes I, II, III, IVa, and IVb as described [46], with minor modifications to correct mismatches and to match the melting temperatures more closely. Similar gene-specific primers were designed for classes V and VI (Table 3). In preliminary experiments the class II primers gave rise to two PCR products of approximately equal intensity, differing in size by 30 base pairs. These two products were cloned into pCR-4, a TA-cloning vector, and subsequently sequenced. The results showed that the larger product was due to a tandem duplication at the reverse primer. Thus, new primers for the $\beta$-tubulin class II gene were designed. $\beta$-Tubulin cDNA was produced with gene-specific primers for each of the isotype mRNAs and Reflectase reverse transcriptase (Active Motif). Aliquots were used in quantitative real-time PCR to determine independently the relative amount of each isotype cDNA.

To obtain control cDNA template of a known quantity for generation of standard curves, product from PCR reactions was isolated from agarose gels with the CONCERT $^{\mathrm{TM}}$ Rapid Gel Extraction kit (Marligen). The concentration of purified cDNA was determined by analyzing serial dilutions on DNA 500 LabChips (Agilent). Standard curves for each $\beta$-tubulin isotype cDNA were generated with real-time PCR at the same time as data were col- licate samples and no template controls, real-time PCR (iCycler $^{\mathrm{TM}} \mathrm{iQ}$; Bio-Rad) with SYBR Green (Molecular Probes) as the detection method was performed to quantify the mRNA levels for selected breast tissues. The amount of $\beta$-tubulin isotype mRNA in a known amount of total RNA was determined from standard curves.

\section{Results}

Tubulin isotypes in breast tissues by immunohistochemistry

A total of 20 anonymous paired normal and tumor tissue samples were obtained from CHTN (Table 1). Selected breast tissue samples $(n=5)$ were examined by immunohistochemistry for the presence of tubulin isotypes. Thin sections from all five samples (two normal and three tumor) reacted moderately to strongly with monoclonal antibodies against $\beta$-tubulin classes II and I + IV. Both cellular and stromal staining were observed. Figure 4 shows sections from a tumor sample that had relatively high levels of $\beta$-tubulin class III levels by ELISA (Fig. 5C: T18). Some staining with antibody against $\beta$-tubulin class III was also observed, mostly as diffuse background stromal tissue staining (Fig. 4C), although occasionally more specific reactivity occurred. A previous examination of five normal and tumor breast tissues showed similar staining patterns [47]. In that study, antibodies against $\beta$-tubulin classes II and I + IV also reacted moderately to strongly with cells, whereas $\beta$-tubulin class III was found in stromal cells and rarely in punctate, irregular staining patterns, suggesting cross sections of nerve fibers. $\beta$-Tubulin class III in normal tissues is a highly specific marker for neurons $[10,19]$ and we therefore attribute most of the $\beta$-tubulin class III antibody reactivity in the breast tissues 
Figure 4

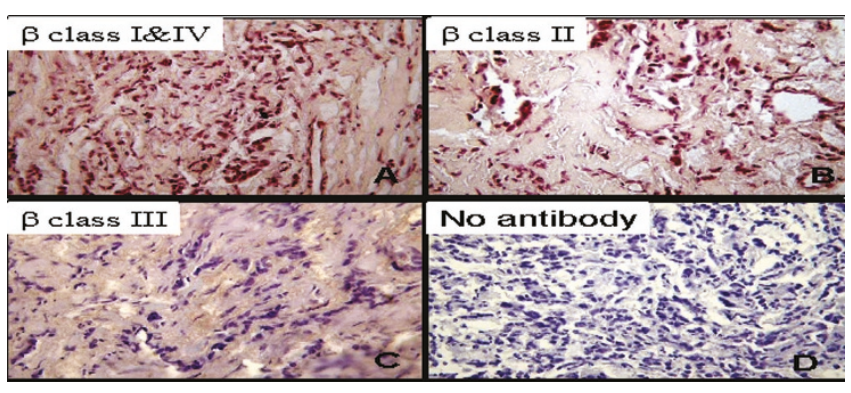

Immunostaining of tumor tissue samples (T18). Thin sections of paraffin-embedded tissue reacted with monoclonal antibody $7 \mathrm{H} 12$, which recognizes $\beta$-tubulin classes I + IV (A); monoclonal antibody 7B9, which recognizes $\beta$-tubulin class II (B); and monoclonal antibody TUJ1, which recognizes $\beta$-tubulin class III (C). (D) No primary antibody. In these panels red staining indicates a positive reaction, and blue staining indicates no reactivity. Note that $(\mathrm{C})$ showed no reactivity with tumor cells, only with background stromal tissue.

to the weak stromal reactivity and presence of nerve fibers.

\section{Quantification of tubulin isotypes in breast tissues by ELISA}

To quantify tubulin isotypes in breast tissue samples $(0.25-1.0 \mathrm{~g})$ we developed a sensitive and reliable indirect ELISA (sensitive to levels of $1 \mu \mathrm{g} / \mathrm{ml}$ tubulin isotype) (Fig. 1). The sensitivity of the ELISA assay was verified by quantitative Western blotting (Figs 2 and 3 ). These results suggested that $\beta$-tubulin classes II and I + IV are the predominant tubulin isotypes in these tissues. This was verified by immunohistochemistry (Fig. 4), which demonstrated strong, specific staining by the antibodies against $\beta$ tubulin classes II and I + IV. In the work presented here, each tissue sample was examined in duplicate on microtiter plates, and triplicate plates were measured to obtain means and standard deviations for each isotype (Fig. 5). There was no difference in tubulin isotype levels in normal and tumor tissues. The predominant isotype fraction was $\beta$-tubulin class II $(0.58 \pm 0.09$ of the total). Both $\beta$-tubulin classes III and I + IV were expressed in smaller amounts in all tissues $(0.17 \pm 0.08$ and $0.26 \pm 0.08$, respectively). Figures $5 \mathrm{~A}$ and $5 \mathrm{~B}$ show $\beta$-tubulin classes I + IV and II plotted as a percentage of total tubulin (excluding $\beta$-tubulin class III, as discussed above), showing that in each tissue sample $\beta$-tubulin class II predominated. Figure $5 \mathrm{C}$ shows the distribution of $\beta$-tubulin class III. Several samples had relatively high levels of $\beta$-tubulin class III. Two of these, N16 and T18, were examined by immunohistochemistry to determine whether the high level of $\beta$-tubulin class III might be due to upregulation of this isotype in tumor or normal cells; however, as discussed above, only stromal staining was observed.
Figure 5
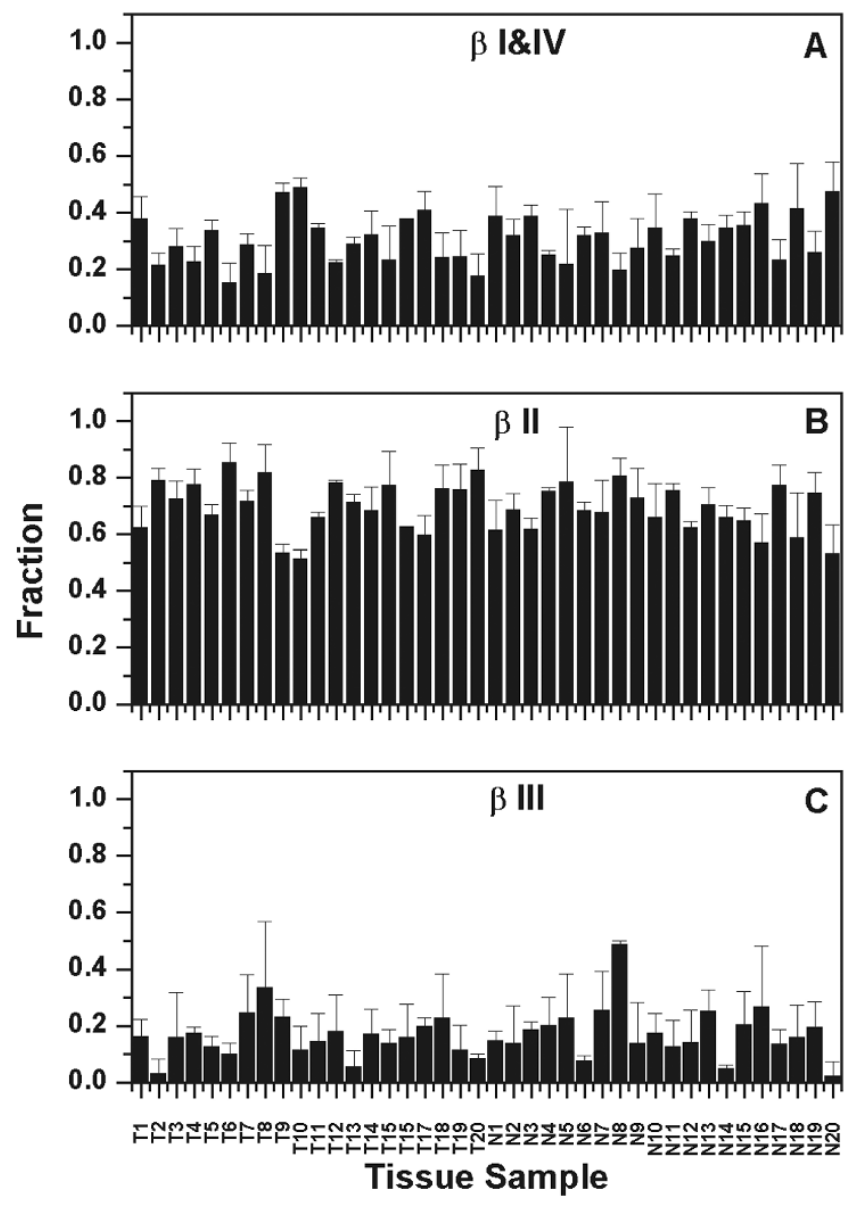

Bar graph showing quantification of $\beta$-tubulin classes I + IV (A), II (B), and III (C) by ELISA. Tumor and normal samples are designated T or $\mathrm{N}$ as defined in Table 1. Results are means and SDs determined from three ELISAs for each tissue sample. The means for $\beta$-tubulin classes I + IV and II were calculated without the contribution from $\beta$ class III tubulin, which is known to be neuron-specific and was shown by immunohistochemistry on these tissues to be due to the presence of nerve fibers.

The fraction of $\beta$-tubulin class II in tissues varied from 0.41 to 0.76 (Fig. 6). Figure 6A shows the similar distributions of $\beta$-tubulin class II in both normal and tumor tissues. Figure $6 \mathrm{~B}$ indicates the relative frequencies of fractions of $\beta$-tubulin class II, demonstrating a Gaussian distribution for the tissue samples. Student $t$-tests comparing normal and tumor tissue samples showed no difference in mean fraction of $\beta$-tubulin class II $(0.60 \pm 0.10$ and $0.56 \pm 0.07$ for tumor and normal tissues, $t=-1.454$ and $P=0.15$ ). (Student $t$-tests for tumor versus normal $\beta$-tubulin classes III or I + IV also showed no significant difference: $t=0.776, P=0.44$; and $t=0.741, P=0.46$.) The varying amounts of isotypes in these tissue samples suggest that isotype levels might be correlated with other biomarkers of poor prognosis. 
Figure 6
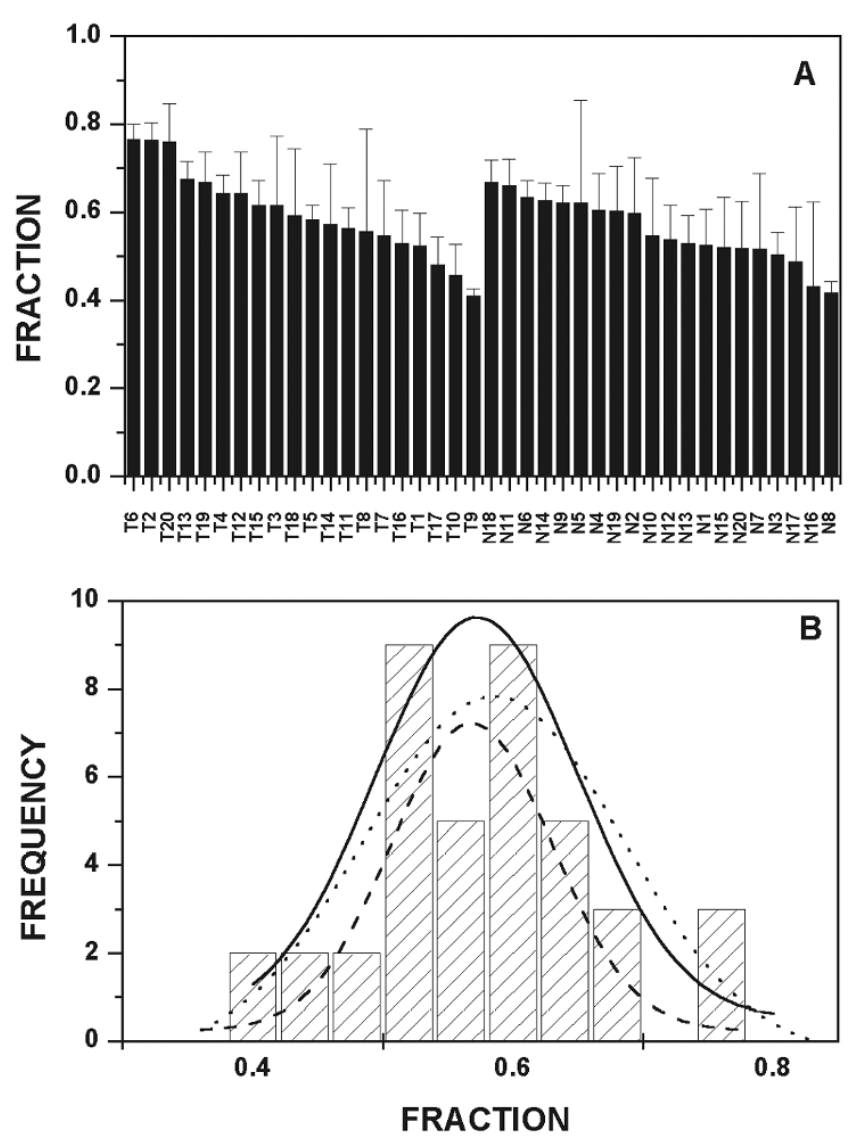

Distribution of $\beta$-tubulin class II in tumor and normal tissue samples. (A) Fractions of $\beta$-tubulin class II ranked in descending order. Tumor and normal samples are designated as in Table 1. The fraction of $\beta$-tubulin class II was calculated as the proportion of the total tubulin, including $\beta$-tubulin classes I + IV and III. The distribution was similar when $\beta$-tubulin class III was not included (data not shown). (B) Frequency distribution for all data in (A). Gaussian fits of the data are superimposed: solid line, all data; broken line, normal tissue; dotted line, tumor tissue. The mean fraction of $\beta$-tubulin class II in tumor tissues is $0.60 \pm 0.10$ and for normal tissue it is $0.56 \pm 0.07$. Student $t$-test comparing the normal and tumor tissue data showed no significant difference $(t=-1.45429, P=0.15)$.

\section{Correlation of $\beta$-tubulin isotype protein and mRNA levels}

To establish whether $\beta$-tubulin isotype protein levels could be inferred from mRNA levels, we used quantitative realtime PCR to measure $\beta$-tubulin mRNA levels in selected breast tissues (Table 1: T1, N1, T4, N4, T12, N12, T13, N13, T15, N15, T18, N18, N6, and T14) (Fig. 7). These data show a broad distribution of mRNA content for all seven $\beta$-tubulin isotype classes. The lowest levels were found for $\beta$-tubulin classes IVa and VI. The ranges of tubulin levels for the other five isotype classes were similar. Although differences between matched tumor and
Figure 7

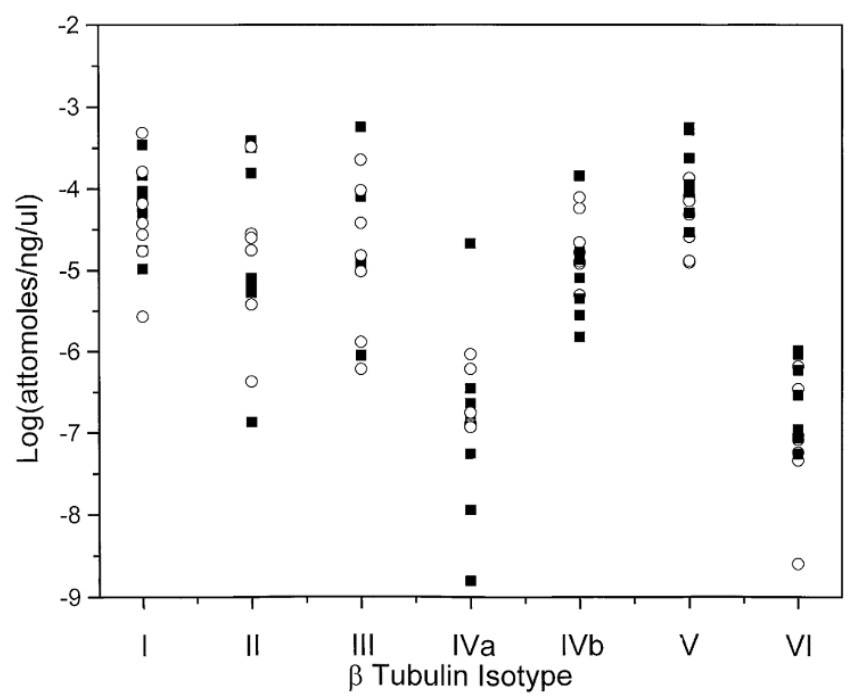

Plot of the quantity of mRNA in selected breast tissues (Table 1: T1, $\mathrm{N} 1, \mathrm{~T} 4, \mathrm{~N} 4, \mathrm{~T} 12, \mathrm{~N} 12, \mathrm{~T} 13, \mathrm{~N} 13, \mathrm{~T} 15, \mathrm{~N} 15, \mathrm{~T} 18, \mathrm{~N} 18, \mathrm{~N} 6$, and T14) for each $\beta$-tubulin isotype class (I, II, III, IVa, IVb, V, and VI). The data are plotted as log attomoles of normalized cDNA to the total RNA concentration in the sample. Open symbols, normal tissue; filled symbols, tumor tissue.

suggesting the upregulation or downregulation of specific tubulin isotypes in tumor tissues compared with normal (data not shown). When the fraction of mRNA for $\beta$-tubulin classes I + IV, II, and III were plotted against the corresponding fraction of protein, it became evident that there is no correlation between tubulin mRNA and protein levels in these tissues (Fig. 8).

\section{Comparison of Her2/neu and $\boldsymbol{\beta}$-tubulin class II expression} In an attempt to understand the significance of the distributions of $\beta$-tubulin classes II and I + IV in normal and tumor breast tissues, we used ELISAs to quantify the Her2/neu protein levels in these tissues. Expression of Her2/neu is amplified in $30 \%$ of all breast tumors and data suggest that it might be a negative prognostic indicator [48]. Figure 9A shows the levels of Her2/neu protein normalized for total protein in tumor and normal tissues. Higher Her2/neu levels were found in all tumor tissues compared with normal tissues. This result verifies the pathology reports (Table 1) that describe the tumor samples as tumors. Note that one 'normal' tissue, N12, was shown to have relatively high levels of Her2/neu protein. However, an independent pathology report on this tissue sample indicated a significant number of tumor cells throughout the entire breast tissue, even though the 'normal' sample was excised at a site distant from the tumor.

The increase of Her2/neu protein in tumor tissues compared with normal tissues is shown in Fig. $9 \mathrm{~B}$ to be from 
Figure 8

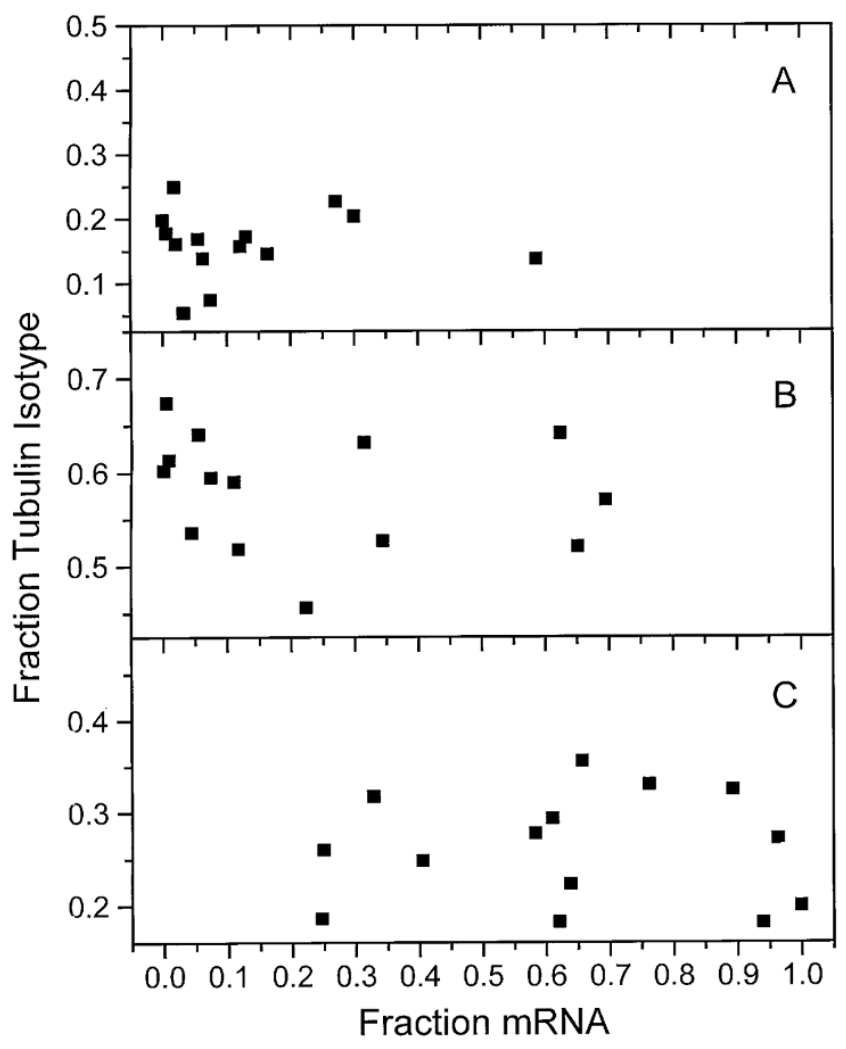

Correlation of $\beta$-tubulin isotype protein and mRNA levels for $\beta$-tubulin classes I + IV, II, and III. In these calculations total tubulin was determined by summation of $\beta$-tubulin isotype classes I + IV, II, and III. The fraction of each isotype was determined relative to this total.

(A) $\beta$-Tubulin class III; (B) $\beta$-tubulin class II; (C) $\beta$-tubulin classes I + IV.

5 -fold to more than 30-fold. The inset in Fig. 9A compares Her2/neu protein levels in a breast cancer cell line that overexpresses Her2/neu with one that does not. The increase in the Her2/neu overexpressing cells is more than 40 -fold. We infer from these data that the breast tumor tissues approaching this level of Her2/neu expression would have significantly increased Her2/neu levels. Plots of Her2/neu protein (Fig. 10A) or fold increase in Her2/neu protein (Fig. 10B) against $\beta$-tubulin class II fraction demonstrate no significant correlation. There is therefore no relationship between tubulin isotype levels and Her2/neu protein expression.

\section{Discussion}

$\beta$-Tubulin class II predominates in breast tissues

This is the first quantitative comparison of tubulin isotype protein levels in human tissues. Previous work has indicated that vertebrate tissues vary in their tubulin isotype composition. $\beta$-Tubulin class $\|$ predominates in brain tissues and has been found in smaller amounts in other tissues [19,45]. Classes III and IVa are primarily found in neurons, whereas classes I and IVb are found in many
Figure 9
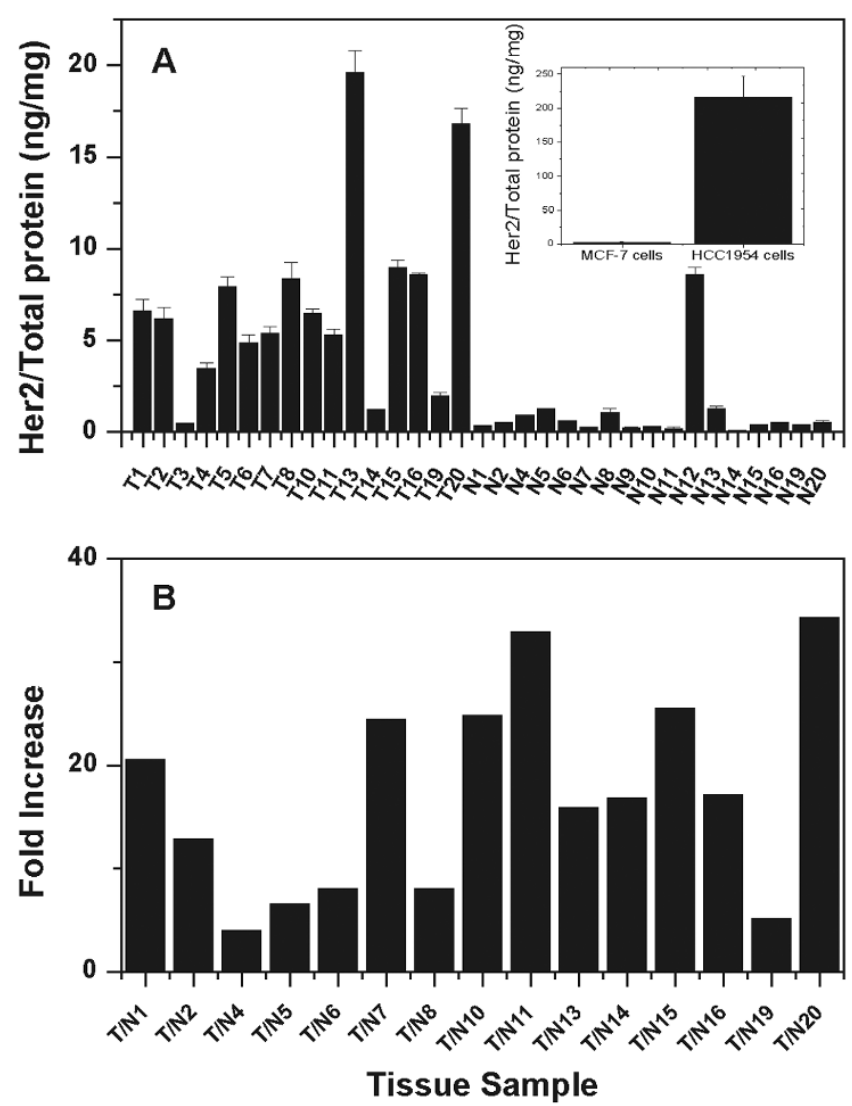

Bar graph of Her2/neu protein in tissue samples quantified by ELISA. (A) Her2/neu normalized for total protein for each tissue sample tested. Sufficient quantities of only 32 of the 40 tissue samples were available for testing. Error bars show SDs for duplicate ELISA plates. The inset compares the total amount of Her2/neu protein in two breast cancer cell lines: MCF-7 cells, which have fewer than five copies of the Her2/neu gene, and HCC1954 cells, which overexpress the Her2/neu protein. Overexpression in this cell line leads to a 40-fold increase in Her2/neu protein level relative to that in MCF-7 cells. (B) Relative amounts of Her2/neu protein in tumor tissue compared with the paired normal tissue, showing the fold increase in Her2/neu for tumor tissues ranging from about 5-fold to more than 30 -fold.

tissues $[10,19]$. $\beta$-Tubulin class $V$ is present in small amounts in many cell types [11] and class $\mathrm{VI}$ is found in blood cells and hematopoietic tissues [49,50]. Much of this quantitative work was done by comparing mRNA levels. However, mRNA and protein levels are not correlated for many human and yeast proteins, especially those that are regulated by post-transcriptional processes [51-53], although there is controversy regarding correct statistical analysis and interpretation of some of these data [54]. Intracellular tubulin levels are under both transcriptional and post-transcriptional control. Fine-tuning of tubulin levels during the cell cycle occurs by autoregulation. This process alters mRNA stability and requires both an essential sequence on polysomal $\beta$-tubulin mRNA and 


\section{Figure 10}
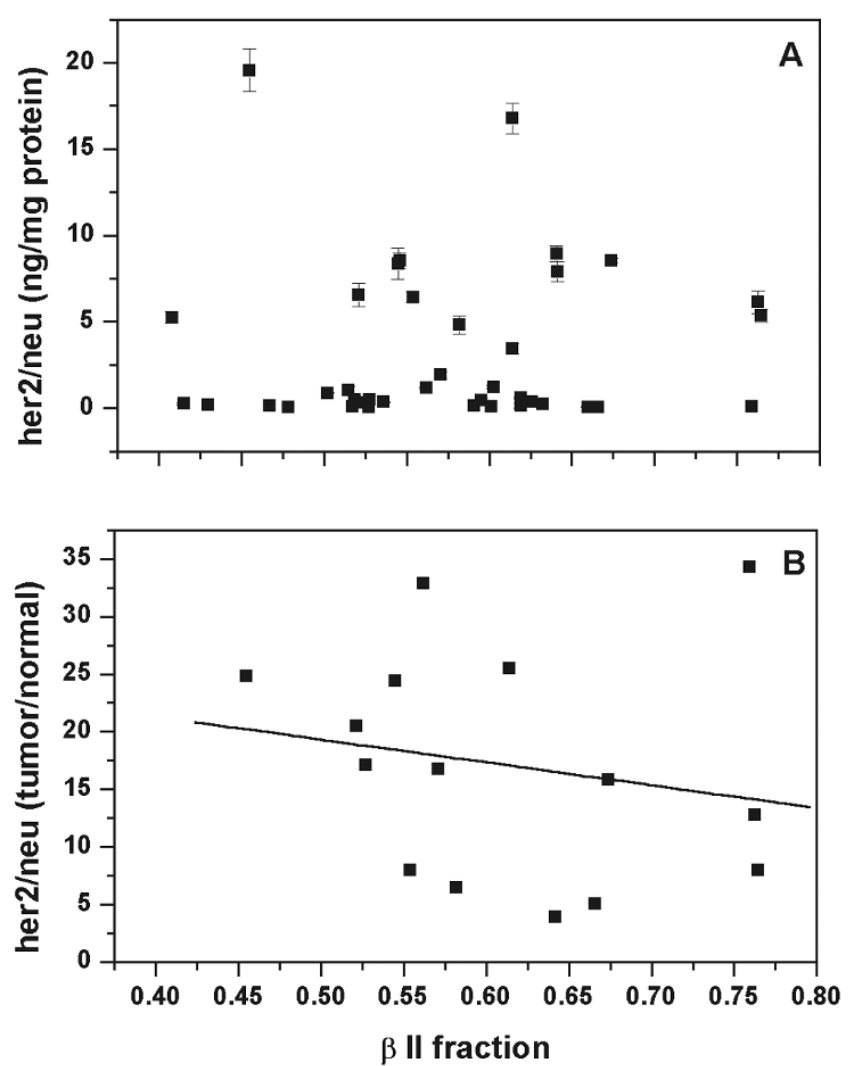

Scatter plots showing the relationship of $\beta$-tubulin class II to Her2/neu protein for each tissue sample. (A) The normalized Her2/neu protein from Fig. 9A plotted against $\beta$-tubulin class II. (B) The fold increase in Her2/neu from Fig. 9B plotted against $\beta$-tubulin class II. The line represents a least-squares linear fit of the data, demonstrating no correlation $(r=-0.193, P=0.491)$.

an amino-terminal Met-Arg-Glu-lle sequence on the nascent tubulin polypeptide [55-57]. Furthermore, $\alpha$ tubulin mRNA levels remain high even when protein synthesis is repressed [58]. In fact, $\alpha$-tubulin synthesis in $\mathrm{CHO}$ cells seems to have a role in regulating $\beta$-tubulin protein levels.

This phenomenon of tubulin post-transcriptional autoregulation was demonstrated in a wide variety of vertebrate and invertebrate cell types. It suggests that individual tubulin isotype protein levels are all similarly regulated, although this has not been demonstrated. Because the total amount of intracellular tubulin depends on both mRNA stability and protein half-life, these data together indicate that high levels of tubulin mRNA might be associated with low levels of free tubulin subunits. This is supported by the recent mass spectrometry and isoelectric focusing work that demonstrated a lack of correlation between tubulin isotype protein levels and mRNA levels in levels are currently interpreted by most investigators as directly representing the total intracellular tubulin protein pool. One alternative to mRNA quantification is immunostaining. Although immunostaining of cells is useful for localizing proteins in tissues and cells, accurate quantification by this method is difficult [41]. Nevertheless, quantitative measurement of protein levels is crucial for understanding intracellular events. In our studies, quantitative real-time PCR data from selected breast tissue samples revealed that $\beta$-tubulin mRNA and protein levels are not correlated. These results indicate that quantitative studies of $\beta$-tubulin isotypes that are done exclusively with PCR techniques should be interpreted with caution because functional protein levels cannot be inferred.

Consistent with our results is the finding of both $\beta$-tubulin classes I and II by immunostaining in many human tissues and cell types [60]. To understand the relationship between the drug target levels and the development of drug resistance, it is essential to know the actual protein amounts in tissues and cells. We demonstrate here by a quantitative ELISA assay that the $\beta$-tubulin class II protein is on average the most abundant isotype in human breast tissues. We found a distribution of $\beta$-tubulin class II levels, ranging from 0.41 to 0.76 . This wide distribution was not expected, because our study of tubulin isotypes in pig brains showed very little brain-to-brain variation. To evaluate the significance of the distribution of $\beta$-tubulin classes II and I + IV in breast tissues, we measured the tissue levels of Her2/neu protein, known to be amplified in 30\% of all breast tumors and associated with poor prognosis [48]. All tumor tissues expressed higher levels of Her2/neu relative to normal tissues. However, there was no correlation between this biomarker and levels of $\beta$-tubulin classes II or I + IV isotype levels. Thus the significance of the range of isotype levels in breast tissues remains unknown. Although it is possible that $\beta$-tubulin class II levels might be correlated with a prognostic biomarker not yet examined [61], these results suggest that a normal patient-to-patient variation might exist.

The ELISA method described here involves total extraction of tubulin and does not differentiate between polymerizable and nonpolymerizable tubulin fractions. There are reports of tubulin isotypes that are differentially incorporated into microtubule structures [62]. However, it is not possible to fractionate microtubules from total cytoplasmic tubulin with quick-frozen human tissue samples. Current experiments are exploring this aspect of tubulin isotype utilization in cell culture studies. One complexity in our work is the sampling of breast tissue. It is possible that samples are composed of different amounts of heterogeneous cell types. However, because our data show similar isotype amounts in normal and tumor breast tissues, differential tissue sampling seems not to be an issue in these experiments. Our method is based in part on an ELISA assay 
developed by Thrower and colleagues [63] for tubulin extracts. This work fulfills their suggestion to quantify changes in tubulin isotype levels with the appropriate antibodies, and establishes a sensitive and accurate assay to complement mRNA assays and studies of the response of cultured cells to antimitotic drugs.

The patient diagnoses for these tumor samples were most commonly infiltrating ductal carcinoma (12 of 20 samples). We found no correlations between tubulin isotype levels and any of the variables given in the pathology reports (estrogen receptor, progesterone receptor, age, race, or histology grade). It should be noted that the 'normal' breast tissues examined in this study were excised from a site distal to the tumor site but in the same breast. Histological examination of the 'normal' tissues indicates the presence of fibrocystic changes in many of the samples and therefore, although these changes are not uncommon in normal aging, they cannot be classified as truly 'normal' breast tissue. However, independent pathology reports determined that the 'normal' tissues were 'non-tumor' tissues with the exception of $\mathrm{N} 1, \mathrm{~N} 12$, and $\mathrm{N} 13$, in which tumor cells were noted. $\mathrm{N} 1$ and $\mathrm{N} 13$ were estimated to contain more than $5 \%$ tumor cells. N12, however, had tumor cells throughout the breast tissue and therefore although the 'normal' sample was taken distal to the tumor it contained significant numbers of tumor cells. N12 was also shown in our ELISA studies to have relatively high levels of Her2/neu protein. Thus, the Her2/neu ELISAs provided a second means of grossly differentiating between 'tumor' and 'normal' tissues for these patients.

It is important to note that many tumor tissues do not express Her2/neu; it is therefore not a generally useful marker for differentiating between tumor and normal tissues. In addition, our work demonstrates that although $\beta$-tubulin class III is a marker for aggressive neuroendocrine tumors $[36,64]$, it is not a significant biomarker in breast tumors. We speculate that this is because breast tissue rarely dysregulates to neuroendocrine cell types.

\section{Tumor and normal breast tissues have similar tubulin isotype levels}

Over the past decade paclitaxel and docetaxel have become important chemotherapeutic agents for both ovarian and breast cancers [1,2]. Considerable interest has focused on the target receptor - tubulin - and mechanisms underlying efficacy, toxicity, and drug resistance $[7,8,23,24,27,28]$. Whether tubulin isotype levels might determine cellular responses to antimitotic agents remains controversial. For example, paclitaxel-resistant lung cancer cells and ovarian tumors were shown to have increased levels of tubulin isotypes, particularly $\beta$-tubulin classes III and IVa [28]. Furthermore, when paclitaxel-resistant lung cancer cells were treated with antisense oligonucleotides for $\beta$-tubulin class III, the drug resistance was partly reversed, coincident with decreased protein levels of $\beta$-tubulin class III [65]. However, it should be noted that $\beta$-tubulin classes I, II, III, and IVa all increased significantly in paclitaxel-resistant lung cancer cells, indicating that the drug effect did not uniquely involve a single tubulin isotype. In other work, $\beta$-tubulin classes III and IVa were shown to increase in paclitaxel-resistant prostate cancer cells [29]. However, these two isotypes continued to be expressed in the lowest amounts.

In ovarian cancer cells, mutations in residues near the putative paclitaxel-binding site of $\beta$-tubulin class I were found in paclitaxel-resistant ovarian cancer cells [23]. Other work suggests that changes in tubulin isotypes alone cannot confer resistance to antimitotics. It was demonstrated that one group of antimitotic agents, vinca alkaloids, bind with similar affinity to all $\beta$-tubulin isotypes [12], thus suggesting for therapy with vinorelbine, vinblastine, or vincristine that tubulin isotype levels are incidental for efficacy. Furthermore, transfection of $\mathrm{CHO}$ cells with $\beta$-tubulin classes I, II, or IVb did not produce resistance to paclitaxel [32]. The alternative hypothesis, derived from the work of Cabral and colleagues, is that rather than the tubulin isotype levels, the amount of polymerized tubulin is the critical factor that regulates response to antimitotic drugs. For example, total amounts of polymerizable tubulin are decreased in paclitaxel-resistant cells, whereas colcemid-resistant tubulin or vinca alkaloid-resistant cells have increased levels of assembled tubulin $[34,66,67]$. Furthermore, when cells were transfected with $\beta$-tubulin class III, weak resistance to paclitaxel was found, and this resistance was associated with decreased microtubule stability [68]. This is consistent with the different modes of action of these drugs: paclitaxel stabilizes microtubules and colcemid inhibits tubulin assembly. In support of this hypothesis, tubulin mutations consistent with altered assembly properties have been identified in paclitaxelresistant and vinca alkaloid-resistant cells $[33,66,69]$.

\section{Conclusion}

We demonstrate that normal and tumor breast tissues, before chemotherapy or radiation treatment, have broad distributions of $\beta$-tubulin isotypes. Furthermore, $\beta$ class II tubulin predominates in most breast tissues. The $\beta$-tubulin isotype levels in normal and tumor tissue are not significantly different and are therefore unlikely to contribute to differential responses of tumors to antimitotic agents. The initial drug sensitivity might depend upon the levels of polymerized tubulin in normal versus tumor tissues associated with the differential expression of MAPs and dynamics regulators such as stathmin [70], a hypothesis currently being explored in our laboratory. The work presented here describes untreated tumors and should be useful for comparison with paclitaxel-treated tumors as a basis for evaluating tubulin isotype levels in response to therapy or in the development of drug resistance. 


\section{Competing interests}

None declared.

\section{Acknowledgements}

We thank Richmond McCarty and Cynthia Stone-Hunter for technical assistance, and also Pelahatchie Country Meat Packers for providing pig heads for tubulin purification. This study was supported by $\mathrm{NIH}$ grant NR04780 (to SL and JJC).

\section{References}

1. Kennedy MJ, Donehower RC, Rowinsky EK: Treatment of metastatic breast cancer with combination paclitaxel/ cyclophosphamide. Semin Oncol 1995, 22(4) Suppl 8:23-27.

2. Davidson NG: Single-agent paclitaxel at first relapse following adjuvant chemotherapy for breast cancer. Semin Oncol 1995, 22 Suppl 14:2-6.

3. Jordan MA, Thrower D, Wilson L: Mechanism of inhibition of cell proliferation by vinca alkaloids. Cancer Res 1991, 51: 2212-2222.

4. Dhamodharan R, Jordan MA, Thrower D, Wilson L, Wadsworth P: Vinblastine suppresses dynamics of individual microtubules in living interphase cells. Mol Biol Cell 1995, 6:1215-1229.

5. Toso RJ, Jordan MA, Farrell KW, Matsumoto B, Wilson L: Kinetic stabilization of microtubule dynamic instability in vitro by vinblastine. Biochemistry 1993, 32:1285-1293.

6. Panda D, Jordan MA, Chu KC, Wilson L: Differential effects of vinblastine on polymerization and dynamics at opposite microtubule ends. J Biol Chem 1996, 271:29807-29812.

7. Yvon AMC, Wadsworth P, Jordan MA: Taxol suppresses dynamics of individual microtubules in living human tumor cells. Mol Biol Cell 1999, 10:947-959.

8. Derry WB, Wilson L, Jordan MA: Substoichiometric binding of taxol suppresses microtubule dynamics. Biochemistry 1995, 34:2203-2211.

9. Parness J, Horwitz SB:Taxol binds to polymerized tubulin in vitro. J Cell Biol 1981, 91:479-487.

10. Sullivan KF, Cleveland DW: Identification of conserved isotypedefining variable region sequences for four vertebrate $\beta$ tubulin polypeptide classes. Proc Natl Acad Sci USA 1986, 83: 4327-4331.

11. Sullivan KF: Structure and utilization of tubulin isotypes. Annu Rev Cell Biol 1988, 4:687-716.

12. Lobert S, Frankfurter A, Correia JJ: Energetics of vinca alkaloid interactions with tubulin isotypes: implications for drug efficacy and toxicity. Cell Motil Cytoskel 1998, 39:107-121.

13. Lobert S, Frankfurter A, Correia JJ: Binding of vinblastine to phosphocellulose-purified and $\alpha \beta$-class III tubulin: the role of nucleotides and $\beta$-tubulin isotypes. Biochemistry 1995, 34: $8050-8060$

14. Lee MK, Tuttle JB, Rebhun LI, Cleveland DW, Frankfurter A: The expression and posttranslational modification of neuronspecific $\beta$-tubulin isotype during chick embryogenesis. Cell Motil Cytoskel 1990, 17:118-132.

15. Lewis SA, Gu W, Cowan NJ: Free intermingling of mammalian $\beta$-tubulin isotypes among functionally distinct microtubules. Cell 1987, 49:539-548.

16. Lopata MA, Cleveland DW: In vivo microtubules are copolymers of available $\beta$-tubulin isotypes: localization of each of six vertebrate $\beta$-tubulin isotypes using polyclonal antibodies elicited by synthetic peptide antigens. J Cell Biol 1987, 105: 1707-1720

17. Luduena RF: Are tubulin isotypes functionally significant? $\mathrm{Mol}$ Biol Cell 1993, 4:445-457.

18. Raff EC: The role of multiple tubulin isoforms in cellular microtubule function. In Microtubules. Edited by Hyams JS, Lloyd CW. New York: Wiley-Liss Inc; 1994:85-109.

19. Lewis SA, Gwo-Shu Lee M, Cowan NJ: Five mouse tubulin isotypes and their regulated expression during development. $J$ Cell Biol 1985, 101:852-861.

20. Hoffman PN, Cleveland DW: Neurofilament and tubulin expression recapitulates the developmental program during axonal regeneration: induction of a specific $\beta$-tubulin isotype. Proc Natl Acad Sci USA 1988, 85:4530-4533.

21. Banerjee A, D'Hoore A, Engelborghs $Y$ : Interaction of desacetamidocolchicine a fast binding analogue of colchicine with isotypically pure tubulin dimers $\alpha \beta I I, \alpha \beta I I$ and $\alpha \beta I V$. J Biol Chem 1994, 269:10324-10329.

22. Lu Q, Luduena RF: Removal of $\beta$ III isotype enhances taxol induced microtubule assembly. Cell Struct Funct 1993, 18: 173-182.

23. Giannakakou P, Sackett DL, Kang Y-K, Zhan A, Buters JTM, Fojo T, Poruchynsky MS: Paclitaxel-resistant human ovarian cancer cells have mutant $\beta$-tubulins that exhibit impaired paclitaxeldriven polymerization. J Biol Chem 1997, 272:17118-17125.

24. Derry WB, Wilson L, Khan IA, Luduena RF, Jordan MA: Taxol differentially modulates the dynamics of microtubules assembled from unfractionated and purified $\beta$-tubulin isotypes. Biochemistry 1997, 36:3554-3562.

25. Laing N, Dahllof B, Hartley-Asp B, Ranganathan S, Tew K: Interaction of estramustine with tubulin isotypes. Biochemistry 1997, 36:871-878.

26. Falconer MM, Echeverri CJ, Brown DL: Differential sorting of $\beta$ tubulin into colchicine stable microtubules during neuronal and muscle differentiation in embryonal carcinoma cells. Cell Motil Cytoskel 1992, 21:313-325.

27. Haber M, Burkhart CA, Regl DL, Madafiglio J, Norris MD, Horwitz SB: Altered expression of $m \beta 2$ the class II $\beta$-tubulin isotype in murine $\mathbf{J 7 7 4} 2$ cell line with a high level of taxol resistance. $J$ Biol Chem 1995, 271:31269-31275.

28. Kavallaris M, Kuo DY-S, Burkhart CA, Regl DL, Norris MD, Haber M, Horwitz SB: Taxol-resistant epithelial ovarian tumors are associated with altered expression of specific $\beta$-tubulin isotypes. J Clin Invest 1997, 100:1282-1293.

29. Ranganthan S, Benetatos CA, Colarusso PJ, Dexter DW, Hudes GR: Altered $\beta$-tubulin isotype expression in paclitaxel-resistant human prostate carcinoma cells. $\mathrm{Br} J$ Cancer 1998, 77: 562-566.

30. Monzo M, Rosell R, Sanchez JJ, Lee JS, O'Brate A, GonzalezLarriba JL, Alberola V, Lorenzo JC, Nunez L, Ro JY, Martin C: Paclitaxel resistance in non-small-cell lung cancer associated with beta-tubulin gene mutations. J Clin Oncol 1999, 17:17861793.

31. Sangrajrang S, Denoulet $P$, Laing NM, Tatoud R, Millot G, Calvo $F$, Tew KD, Fellous A: Association of estramustine resistance in human prostatic carcinoma cells with modified patterns of tubulin expression. Biochem Pharmacol 1998, 55:325-331.

32. Blade K, Menick DR, Cabral F: Overexpression of class I, II or IVb $\beta$-tubulin isotypes in $\mathrm{CHO}$ cells is insufficient to confer resistance to paclitaxel. J Cell Sci 1999, 112:2213-2221.

33. Gonzalez-Garay ML, Cabral F: Overexpression of an epitopetagged $\beta$-tubulin in Chinese hamster ovary cells causes an increase in endogenous $\alpha$-tubulin synthesis. Cell Motil Cytoskel 1995, 31:259-272.

34. Minotti AM, Barlow SB, Cabral F: Resistance to antimitotic drugs in Chinese hamster ovary cells correlates with changes in the level of polymerized tubulin. J Biol Chem 1991, 266: 3987-3994.

35. Cabral F, Barlow SB: Resistance to antimitotic agents as genetic probes of microtubule structure and function. Pharmacol Ther 1991, 52:159-171.

36. Katsetos CD, Kontogeorgos G, Geddes JF, Herman MM, TsimaraPapastamatiou G, Yu Y, Sakkas LI, Tsokos M, Patchefsky AS, Ehya H, Coper HS, Provencio J, Spano A, Frankfurter A: Differential distribution of the neuron-associated class III $\beta$-tubulin in neuroendocrine lung tumors. Arch Pathol Lab Med 2000, 124: 535-544.

37. Williams RC Jr, Lee JC: Preparation of tubulin from brain. Methods Enzymol 1982, 85:376-408.

38. Correia JJ, Baty LT, Williams RC Jr: $\mathbf{M g}^{2+}$ dependence of guanine nucleotide binding to tubulin. J Biol Chem 1987, 262: 17278-17284

39. Detrich HW III, Williams RC Jr: Reversible dissociation of the $\alpha \beta$ dimer of tubulin from bovine brain. Biochemistry 1978, 17: 3900-3907.

40. DeFazio A, Chiew Y-E, Sini RL, Janes PW, Sutherland RL: Expression of c-erbB receptors heregulin and oestrogen receptor in human breast cell lines. Int J Cancer 2000, 87:487498.

41. Gazdar AF, Kurvari V, Virmani A, Gollahon L, Sakaguchi M, Westerfield M, Kodagoda D, Stasny V, Cunningham HT, Wistuba II, Tomlinson G, Tonk V, Ashfaq R, Leitch AM, Minna JD, Shary JW: Characterization of paired tumor and non-tumor cells estab- 
lished from patients with breast cancer. Int J Cancer 1998, 78: 766-774.

42. Lacey E, Snowdon KL: Isolation of mammalian brain tubulin by amino-activated gel chromatography. J Chromatogr 1990, 525: 71-84.

43. Towbin H, Staehlin T, Gordon J: Electrophoretic transfer of proteins from polyacrylamide gels to nitrocellulose sheets: procedure and some applications. Proc Natl Acad Sci USA 1979, 76:4350-4354

44. Crowther JR: Indirect ELISA. In Methods in Molecular Biology: ELISA Theory and Practice. Totowa, NJ: Humana Press; 1995:131-160.

45. Banerjee A, Roach MC, Wall KA, Lopata MA, Cleveland DW, Luduena RF: A monoclonal antibody against the type II isotype of $\beta$-tubulin. J Biol Chem 1988, 263:3029-3034.

46. Jaffrezou J-P, Dumontet C, Derry WB, Duran G, Chen G, Tsuchiya E, Wilson L, Jordan MA, Sikic B: Novel mechanism of resistance to paclitaxel (Taxol) in human K563 leukemia cells by combined selection with PSC 833. Oncol Res 1995, 7:517-527.

47. Lobert S, Tucci MA, Benghuzzi HA, Frankfurter A, Correia JJ: Tubulin isotypes in normal and tumor breast tissue. Mol Biol Cell 1998, 9 (Suppl): 151a.

48. Slamon DJ, Clark GM, Wong SG, Levin WJ, Ullrich A, McGuire WL: Human breast cancer: correlation of relapse and survival with amplification of the Her-2/neu oncogene. Science 1987, 235:177-181

49. Wang $D$, Villasante $A$, Lewis $S A$, Cowan NJ: The mammalian $\beta$ tubulin repertoire hematopoietic expression of a novel heterologous $\beta$-tubulin isotype. J Cell Biol 1986, 103:1903-1910.

50. Murphy DB, Wallis KT: Brain and erythrocyte microtubules from chicken contain different $\beta$-tubulin polypeptides. J Biol Chem 1983, 258:7870-7875.

51. Gygi SP, Rochon Y, Franza R, Aebersold R: Correlation between protein and mRNA abundance in yeast. Mol Cell Biol 1999, 19: 1720-1730.

52. Anderson L, Seilhamer J: A comparison of selected mRNA and protein abundances in human liver. Electrophoresis 1997, 18: 533-537.

53. Tew KD, Monks A, Barone L, Rosser D, Akerman G, Montali JA, Wheatley JB, Schmidt DE Jr: Glutathione-associated enzymes in the human cell lines of the National Cancer Institute drug screening program. Mol Pharmacol 1996, 50:49-159.

54. Futcher B, Latter GI, Monardo P, McLaughlin CS, Garrels JI: A sampling of the yeast proteome. Mol Cell Biol 1999, 19:73577368.

55. Cleveland DW: Autoregulated control of tubulin synthesis in animal cells. Curr Opin Cell Biol 1989, 1:10-14.

56. Pachter JS, Yen TJ, Cleveland DW: Autoregulation of tubulin expression is achieved through specific degradation of polysomal tubulin mRNAs. Cell 1987, 51:283-292

57. Yen TJ, Machlin PS, Cleveland DW: Autoregulated instability of $\beta$-tubulin mRNAs by recognition of the nascent amino terminus of $\beta$-tubulin. Nature 1988, 334:580-585.

58. Gonzalez-Garay ML, Cabral F: $\alpha$-Tubulin limits its own synthesis: evidence for a mechanism involving translational repression. J Cell Biol 1996, 135:1525-1534.

59. Verdier-Pinard P, Wang F, Martello, L, Burd, B, Orr, GA, Horwitz $\mathrm{SB}$ : Analysis of tubulin isotypes and mutation from taxolrestant cells by combined isoelectrofocusing and mass spectrometry. Biochemistry 2003, 42:5349-5357.

60. Roach MC, Boucher VL, Walss C, Ravdin PM, Luduena RF: Preparation of a monoclonal antibody specific for class I isotype of $\beta$ tubulin: the $\beta$ isotypes of tubulin differ in their cellular distributions within human tissues. Cell Motil Cytoskel 1998, 39:273-285

61. Miahe A, Lafanechere L, Treilleux I, Peloux N, Dumontet C, Bremond A, Panh M-H, Payan R, Wehland J, Margolis R-L, Job D: Tubulin detryrosination is a frequent occurrence in breast cancers of poor prognosis. Cancer Res 2001, 61:5024-5027.

62. Joshi $H$, Cleveland D: Differential utilization of $\beta$-tubulin isotypes in differentiating neurites. J Cell Biol 1989, 109:663673.

63. Thrower D, Jordan MS, Wilson L: A quantitative solid-phase assay for tubulin. Methods Cell Biol 1993, 37:29-145.

64. Draberova E, Lukas Z, Ivanyi D, Viklicky V, Draber P: Expression of class III $\beta$-tubulin in normal and neoplastic human tissues. Histochem Cell Biol 1998, 109:231-239.
65. Kavallaris M, Burkhart CA, Horwitz SB: Antisense oligonucleotides to class III $\beta$-tubuli sensitize drug-resistant cells to taxol. Br J Cancer 1999, 80:1020-1025.

66. Sawada T, Cabral F: Expression and function of $\beta$-tubulin isotypes in Chinese hamster ovary cells. J Biol Chem 1989, 264: 3013-3020.

67. Kavallaris M, Tait AS, Walsh BJ, He L, Horwitz SB, Norris MD, Haber M: Multiple microtubule alterations are associated with vinca alkaloid resistance in human leukemia cells. Cancer Res 2001, 61:5803-5809.

68. Hari M, Yang H, Canizales M, Zeng C, Cabral F: Expression of class III $\beta$-tubulin in $\mathrm{CHO}$ cells reduces microtubule stability and confers resistance to paclitaxel. Proc Am Assoc Cancer Res 2002, 43:LB139.

69. Gonzalez-Garay ML, Chang L, Blade K, Menick DR, Cabral F: A $\beta$ tubulin leucine cluster involved in microtubule assembly and paclitaxel resistance. J Biol Chem 1999, 274:23875-23882.

70. Cassimeris L: Accessory protein regulation of microtubule dynamics throughout the cell cycle. Curr Opin Cell Biol 1999, 11:134-141.

\section{Correspondence}

Sharon Lobert, School of Nursing, University of Mississippi Medical Center, 2500 N State Street, Jackson, MS 39216, USA. Tel: +1 601 984 1852; fax: +1 601984 6206; e-mail: slobert@son.umsmed.edu 